ORIGINAL ARTICLE

\title{
The dissemination of anthrax from imported wool: Kidderminster 1900-14
}

\section{T Carter}

Correspondence to:

$\mathrm{Dr} T$ Carter, Institute of Occupational Health and Centre for the History of Medicine, University of Birmingham, Birmingham B15 2TT, UK; tim.carter@ virgin.net

Accepted 24 June 2002
Background: A century ago anthrax was a continuing health risk in the town of Kidderminster. The distribution of cases in people and in animals provides an indication of the routes by which spores were disseminated. The response to these cases provides an insight into attitudes to an occupational and environmental risk at the time and can be compared with responses in more recent times.

Aims: To assess the distribution of anthrax cases associated with the use of contaminated wool and to review the response to them.

Methods: The area studied was Kidderminster, Worcestershire, England, from 1900 to 1914. Data sources were national records of the Factory Inspectorate and local records from the infirmary, Medical Officer of Health and inquest reports, and county agricultural records, supplemented by contemporary and later review articles. Case reports and summary data were analysed, and discussions and actions taken to improve precautions reviewed.

Results: There were 36 cases of anthrax, with five deaths, one of which was the sole case of the internal form of the disease. Cases of cutaneous anthrax were most frequently found in those handling raw wool, but they also occurred in workers at later stages of the spinning process and in people with little or no recorded exposure to contaminated wool. Limited precautionary measures were in place at the start of the study period. Some improvements were made, especially in the treatment of infections, but wool with a high risk of anthrax contamination continued to be used and cases continued to arise. Major changes were made to the disposal of waste and to agricultural practice in contaminated areas to curtail outbreaks in farm animals.

Conclusions: The introduction of anthrax as a contaminant of imported wool led not only to cases in the highly exposed groups of workers but also to cases in other members of the population and in farm animals. The measures taken during the study period reduced fatalities from cutaneous anthrax but did not eliminate the disease. Public concern about the cases was muted.
A nthrax was endemic in Middle Eastern flocks one hundred years ago. Bales of contaminated wool were imported into England and these led to cases of anthrax which were recognised in the wool towns of West Yorkshire from the 1880s. ${ }^{1}$ Precautions involving downdraft ventilation and segregation of areas where these bales were opened were introduced and became a regulatory requirement in 1897. ${ }^{2}$ Kidderminster in Worcestershire (Borough population 1901 and 1911 about 28000 ) specialised in carpet weaving but also had a wool spinning industry. ${ }^{3}{ }^{4}$ There is some evidence that not all the wool spun in the town was used there and it is certain that much spun yarn was brought in from other areas to use in carpet weaving. At the turn of the century Kidderminster had the highest incidence of anthrax per 1000 wool workers in the country: 1.6 for the five years 1899-1904 compared with a national industry average of $0.3 .^{5}$

Several sources of information on anthrax in Kidderminster during this period are available. These include The Chief Inspector of Factories Annual Reports (FI), ${ }^{6}$ local council minutes, ${ }^{7}$ Medical Officer of Health reports $(\mathrm{MOH}),{ }^{8}$ and County Council papers on farm infections. ${ }^{9}{ }^{10}$ Kidderminster Infirmary annual reports ${ }^{11}$ provide a useful independent verification of the number of cases. Local papers carry detailed inquest reports ${ }^{12-15}$ and associated commentary. The 1905 Milroy lectures ${ }^{16}$ given by Thomas Legge, the Medical Inspector of Factories, place the Kidderminster cases in a wider context. ${ }^{17}$ This study is based on these sources. Complementary reports are in preparation, which will cover aspects such as the outbreaks in animals, attitudes to responsibility for the risk, and the relationships between the various parties involved in risk management.

\section{THE CASES}

Table 1 provides a summary of the recorded cases of anthrax in Kidderminster. The information is incomplete for the early years. Discrepancies between sources arise from the limited number of occupations for which notification of cases to the Factory Inspectorate was required. As the Inspectorate records improved, the detail in Medical Officer of Health reports became more limited. The highest incidence of both cases and fatalities was in 1903. Cases continued thereafter but fatal cases were rare. Several groups of people were infected but cases were most frequent in those working in spinning mills, especially at the early stages of the process where raw wool was handled.

Several animal outbreaks on the Corporation sewage farm were investigated. Cases in animals also occurred on farms around Kidderminster that used shoddy (wool waste), which could be contaminated with anthrax, as a fertiliser.

\section{THE SOURCE OF INFECTION}

Bales of wool arrived mainly by rail, and were distributed to spinning mills by dray, where they were opened. The fleeces were unpacked, washed, carded, and then spun. Wool from a range of countries was used, but Persian wool caused particular problems. This is confirmed by a circular letter from British users to the consignors of Persian wool, urging 


\section{Main messages}

- Anthrax from contaminated wool was not only a risk to wool workers. Cases also occurred in the community and in farm animals.

- The limited precautions used 100 years ago were inadequate, but there was a reluctance to make them more stringent.

- The acceptability of action to prevent occupational disease has to be viewed in the context of other concurrent risks and changing attitudes to health and to industry.

- Detailed local history studies can provide insights on the interactions between health regulators and those they regulate.

them "to keep out of bales extraneous matter, and secondly to pack locks, fallen wool (that from dead sheep) and skin in separate bales". ${ }^{18}$ At this stage the bacteriology of the wools from various sources had not been investigated. Of 88 UK anthrax cases in the wool industry before 1905 with records of exposure, 29 handled Persian (Baghdad) wool; only two handled native, colonial, or East Indian wool; eight were indefinite; and the rest handled other wools of known high risk such as alpaca and mohair. ${ }^{19}$ Later studies confirmed that the frequency of bacterial isolation aligned with the distribution of cases, that wool from dead sheep was a particularly high risk, and that blood clots and skin fragments in the wool were common sites for bacilli. ${ }^{20}$

\section{WHO BECAME INFECTED}

Occupational descriptions were not standardised and while there is detailed information on some cases, especially where an inquest took place, it is limited in others. Thirty of 36 cases had recorded occupations (table 1). The 1901 census results for the county can be extrapolated to Kidderminster Borough and provide an approximate estimate of numbers in each main group, but they will be underestimates for the population at risk where, as in wool preparation, unskilled labourers are present in significant numbers:

- Eleven worked in the wool reception areas as sorters, washers, or labourers, although one was in a wool warehouse which had not contained Persian wool for over a year (wool sorters and wool combers c.70 employed + uncertain number of labourers).

- Nine worked in carding and spinning. (c.800 employed).

- Two worked in weaving and dyeing. (c.6400 employed).

- There were eight cases elsewhere:

- one drayman who carried wool to mills but had not apparently handled Persian wool for three weeks prior to death

- one each of horse slaughterer, machine oiler (location not specified), brewer's traveller

- two stokers (location not specified)

- two wool sorters' wives.

(Kidderminster-non-textile workers over 10 years of age, occupied and unoccupied c.14 000)

Plausible routes of exposure exist for the drayman, wool sorters' wives, and for the two stokers-as dust and contaminated wool were incinerated. The routes of exposure for the other cases are unknown but could be either via family contacts or related to contact with infected animals.
Policy implications

- The pattern of infection in Kidderminster may be used to help define effective risk management strategies.

- Consensus on a risk and the practicability of control needs to be secured before any preventative action is likely to be successful.

There was a low background incidence of anthrax among farm animals in Worcestershire, but certain outbreaks were firmly attributed to wool waste. Animal cases were sometimes recorded by number of beasts affected but, particularly in the case of pigs and sheep, this is not noted and so a consistent tally cannot be made. ${ }^{10} 2223$

Thus although a large proportion of cases were in the relatively small groups of workers with exposure to unprocessed wool from freshly opened bales, there were cases elsewhere. These may have arisen from external contamination on bales, carry over of bacilli with part processed wool, airborne distribution of bacilli and spores, transfer on clothing, and possibly also secondary to cases in animals infected from wool waste. It is not possible to calculate reliable incidence rates as population denominators are not uniformly available.

\section{PRECAUTIONS}

The most detailed information on precautions comes from the four inquests in November 1902, ${ }^{9}$ March $1903^{10}$ (on two deaths), and November 1903. ${ }^{11}$ At this time all mills were working under the 1897 Special Rules, which required separate rooms for opening bales of high risk wools and tables with downdraught ventilation to reduce airborne spread of dust and hence bacilli. Key deficiencies identified were:

(1) Little information on risks available to workers and lack of awareness of early signs of cutaneous "malignant pustule". An attitude bordering on denial about harm from work in those workers who were at risk.

(2) Poor awareness of anthrax symptoms and signs by doctors, leading to delays in diagnosis.

(3) Ventilation unpopular and sometimes reduced to avoid discomfort of draughts-supervisors colluded with this.

(4) Discharge of extract ventilation from fans to open air, with only limited filtering.

(5) Contaminated wool waste being used as fertiliser.

(6) Ventilation in wool sorting but not in bale opening areas.

(7) Inadequate provision for change of job if a skin abrasion was present.

(8) Poor arrangements for hygiene and disinfection of wool reception areas (and also of drays).

The mill owners largely escaped criticism by appearing contrite and agreeing to remedy defects, as did the doctors for delays in diagnosis. Much of the blame was directed at supervisors for laxness and at the workers themselves for failures of self care or speedy recourse to medical advice. The Factory Inspectorate acted as an investigative questioner as well as being a witness, and the adequacy of their Special Rules or their inspection and enforcement action was not an issue.

\section{ACTION FOLLOWING THE 1903 DEATHS}

There was press coverage locally and some in Yorkshire newspapers. ${ }^{24}$ In March 1903 The Kidderminster Shuttle 


\begin{tabular}{|c|c|c|}
\hline Year & Source of data and summary (total) & Anthrax case details (where available) \\
\hline 1896 & $\begin{array}{l}\text { Fl } 17 \text { in wool industry nationally. No separate Kidderminster data. Comment } \\
\text { "regret that many cases go unreported" } \\
\text { Infirmary 1 (1) }\end{array}$ & \\
\hline 1897 & Infirmary i (1) & \\
\hline 1898 & Infirmary 1 (1) & \\
\hline 1899 & Infirmary $0(0)$ & \\
\hline 1900 & Infirmary 2 (2) & \\
\hline 1901 & Infirmary 1 (excised) (1) & \\
\hline 1902 & $\begin{array}{l}1 \text { fatal-inquest report } \\
\text { Infirmary } 2 \text { (excised 2) (2) }\end{array}$ & M 56 Wool washing-fatal ${ }^{* *}$ \\
\hline 1903 & $\begin{array}{l}6 \mathrm{MOH} \text { and FI, } 3 \text { fatal-inquest reports. } 7 \text { cases in last year alleged at March } \\
\text { inquest, medical witness states } 5 \text { cases at infirmary since November } 1902\end{array}$ & $\begin{array}{l}\text { M } 42 \text { Wool department-fatal }{ }^{* *} \\
\text { M } 46 \text { Drayman-fatal } \\
\text { M } 16 \text { Wool department-fatal }{ }^{* *}\end{array}$ \\
\hline & Infirmary 6 (excised 6) (6) & $\begin{array}{l}\text { M } 46 \text { Wool department** } \\
\text { M } 17 \text { Wool washing }{ }^{* *}\end{array}$ \\
\hline & & M 41 Traveller for Brewery \\
\hline 1904 & $\begin{array}{l}\text { MOH } 2 \\
\text { Infirmary } 2 \text { (excised 3) (2) }\end{array}$ & $\begin{array}{l}\text { F } 35 \text { Wife of woolsorter }<> \\
\text { M16. Wool warehouse }{ }^{* *} \text { (no scheduled wools handled in las } \\
\text { year) }\end{array}$ \\
\hline & FI 12 cases in Kidderminster 1899-1904 & \\
\hline 1905 & $\begin{array}{l}\text { MOH } 2 \text { cases. FI } 3 \text { cases in county } \\
\text { Infirmary } 4 \text { (excised 1) (4) }\end{array}$ & $\begin{array}{l}\text { F age unknown Wife of woolsorter } \\
\text { F } 16 \text { Spinner* } \\
\text { F } 18 \text { Spinner* }^{*}\end{array}$ \\
\hline 1906 & $\begin{array}{l}\text { FI } 2 \\
\text { Infirmary } 1 \text { (excised 0) (2) }\end{array}$ & $\begin{array}{l}\text { F } 26 \text { Spinning }^{*} \\
\text { M } 16 \text { spinning }^{*}\end{array}$ \\
\hline 1907 & $\begin{array}{l}\mathrm{Fl} \text { and } \mathrm{MOH} 3 \\
\text { Infirmary } 3 \text { (excised 0) (3) }\end{array}$ & $\begin{array}{l}\text { F } 17 \text { Spinning finisher* } \\
\text { F } 26 \text { Wool spinner** } \\
\text { F } 22 \text { card feeder** }\end{array}$ \\
\hline 1908 & $\begin{array}{l}\text { MOH } 3 \text { FI nil (3) } \\
\text { Infirmary } 2 \text { (excised 2) }\end{array}$ & $\begin{array}{l}\text { M } 23 \text { Horse slaughterer } \\
\text { M } 30 \text { Carpet mill worker }\end{array}$ \\
\hline 1909 & $\begin{array}{l}\mathrm{FI} \text { and } \mathrm{MOH} 4,1 \text { fatal } \\
\text { Infirmary } 3 \text { (cured 3) (4) }\end{array}$ & $\begin{array}{l}\text { M } 36 \text { packing after blending-fatal }{ }^{* *} \\
\text { (no medical advice sought) } \\
\text { M } 59 \text { Oiled machines } \\
\text { M } 26 \text { Dyehouse worker } \\
\text { M } 25 \text { Wool worker }{ }^{* *}\end{array}$ \\
\hline 1910 & $\begin{array}{l}\text { FI } 1 \\
\text { Infirmary } 1 \text { (cured 1) (1) }\end{array}$ & F 47 Drawing box minder* \\
\hline 1911 & Nil reported (0) & Nil \\
\hline 1912 & $\begin{array}{l}\text { Fl } 1 \\
\text { Infirmary in-patient } 0(1)\end{array}$ & M 30 Woolsorter ${ }^{\star *}$ \\
\hline 1913 & $\begin{array}{l}\text { FI } 1 \\
\text { Infirmary in-patient } 0 \text { (1) }\end{array}$ & M 49 Stoker \\
\hline 1914 & $\begin{array}{l}\text { Fl } 4 \\
\text { Infirmary } 4 \text { all cured (4) }\end{array}$ & $\begin{array}{l}\text { M } 30 \text { Wool blending** } \\
\text { M } 50 \text { Stoker } \\
\text { M } 31 \text { Card dresser } \\
\text { M } 17 \text { Wool washer** }\end{array}$ \\
\hline 1915 & $\begin{array}{l}\text { FI wartime gap in records } 1915 \text { onward } \\
\text { Infirmary 6 - gap } 1916 \text { onward (6) }\end{array}$ & \\
\hline
\end{tabular}

commented in its Carpet Trade column: "It is an open question, having regard to the low price of English and Colonial wools, whether it is necessary to import these Eastern products in the two or three spinning mills of the district where their use is continuing". ${ }^{25}$ Yet use did continue for many years!

The town clerk wrote to all spinning mills on the advice of the $\mathrm{MOH}$, requiring them to contain and burn waste and not to sell it for spreading on the land or blow it into the atmosphere. ${ }^{26}$ This was one of several measures adopted, which also included banning grazing on the sewage farm and certain infected pastures. Their introduction followed a tense meeting of Worcestershire farmers, attended by an inspector from the Board of Agriculture, at which the desirability of ceasing to use potentially infected wools was raised but deemed to be unachievable. ${ }^{27} 28$

Soon afterwards treatment was dramatically improved by the introduction of an antiserum, first produced by Sclavo in Siena. This was regularly used at Kidderminster Infirmary and greatly improved prognosis, speeding recovery and reducing the death rate from cutaneous anthrax markedly. ${ }^{29}{ }^{30} \mathrm{It}$ also lessened the need for the grossly disfiguring facial surgery often required to excise a skin lesion.

In 1905 draft regulations were introduced by the Factory Department which extended the area covered by the 1897 Special Rules.

Awareness among workers was increased by a Factory Department poster, the first of its kind, which showed pictures of the early stages of cutaneous anthrax, with the advice to seek immediate medical attention. ${ }^{31}$ There is no information to show whether the speed of diagnosis improved, but it is noteworthy that the only fatal case in Kidderminster between 1903 and 1914 was in someone with internal anthrax in whom the diagnosis was delayed. The inquest on this case said little about prevention, but concentrated on treatment and whether the deceased could have been saved by serum if it had been given at an early stage.

In the event contaminated wools continued to be used. With more effective treatment and possibly unrecorded improvements in work practice there seems to have been a local acceptance that a few cases of anthrax each year for 


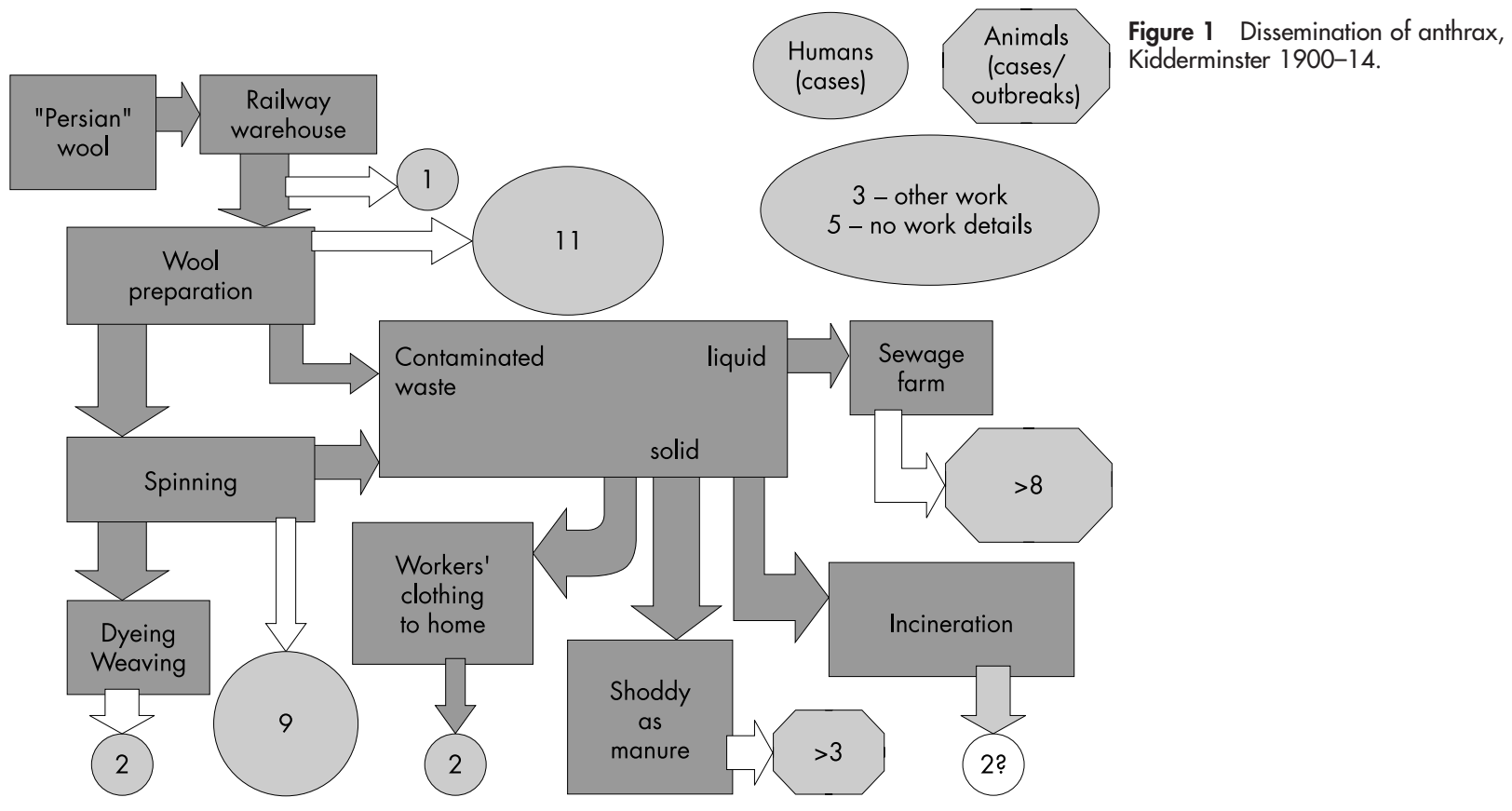

many more years were the price to be paid for spinning high risk wools. The inadequacy of prevention nationally was recognised by the Factory Department and there was a major inquiry in 1914, although the war delayed publication until four years later.

\section{DISCUSSION}

The pattern of anthrax in Kidderminster during the period studied shows the distribution of cases when packages naturally contaminated with the bacillus are delivered and opened with some rather limited precautions and little attention to the details of work practice or to early identification of ill health. It also indicates the scope for spread and some of the routes by which this occurred (fig 1).

The relatively low key response to these cases is in line with attitudes to occupational ill health at the time. It has to be remembered that infectious illness was then far more common and took a greater toll. In 1903, the peak year for anthrax, Kidderminster also had five cases of smallpox, one fatal, ${ }^{33}$ and an epidemic of scarlet fever which, at its peak, led to 87 cases in the local infirmary. ${ }^{34}$

Both the nature of contamination and the response to it in Kidderminster differed from that in recent US outbreaks. Anthrax was present in large volumes of a raw material deemed essential to the prosperity of the town, with the possibility of inhalation, but the major risk being skin contamination from bacilli and spores contained within blood clots and skin fragments associated with the wool. The virulence of the bacillus would depend on prevailing strains in the countries of origin of the wool while the frequency of contamination would be governed by its epidemic status in their flocks. The resistance of the bacillus and its spores meant that, wherever infective material had been deposited, there was a continuing risk, although it would be in proportion to the amount and to the scope for inhalation, ingestion, or contact with damaged skin. The concentration of cases in high exposure areas with a tail of cases where exposure was lower is noteworthy. The cases in both humans and animals where contaminated waste was present, as well as some cases where the source cannot be identified or where contaminated materials had not been used for some while, confirms the potential for persistence and widespread dissemination.

\section{REFERENCES}

1 Legge TM. Industrial Anthrax, Milroy Lectures 1904. Lancet 1905;1(1 April):842.

2 Chief Inspector of Factories. Annual Report. London: HMSO, 1897.

3 Tomkinson K, Hall G. Kidderminster since 1800. Kidderminster: K Tomkinson, 1985 (ISBN 0907080308 0).

4 HMSO. Census of 1901 County of Worcester. HMSO 1902 CD1293 (also $1911,1921)$.

5 Legge TM. Industrial Anthrax, Milroy Lectures 1904. Lancet 1905;1(18 March):689-90.

6 Chief Inspector of Factories. Annual Reports 1897-1917. London: HMSO.

7 Kidderminster Council. Minutes, Local Studies Collection, Kidderminster Library.

8 Medical Officer of Health. Kidderminster monthly and annual reports. Bound with council reports. Local Studies Collection, Kidderminster Library.

9 County Analyst's papers. Worcestershire County Record Office.

10 Contagion subcommittee of Executive Committee. Worcestershire County Council. Minutes in Worcestershire County Record Office.

11 Kidderminster Infirmary. Annual Reports 1890-1919. Worcester County Records Office.

12 Kidderminster Shuttle. 29 November 1902. Microfilm. Local Studies Collection, Kidderminster Library.

13 Kidderminster Times. 14 March 1903. Microfilm. Local Studies Collection, Kidderminster Library.

14 Kidderminster Shuttle. 7 November 1903. Microfilm. Local Studies Collection, Kidderminster Library.

15 Kidderminster Shuttle. 20 November 1909. Microfilm. Local Studies Collection, Kidderminster Library.

16 Legge TM. Industrial Anthrax, Milroy Lectures 1904. Lancet 1905;1:18 March:689-96; 25 March:764-76; 1 April:841-6.

17 Carter T. Sir Thomas Legge: a celebration. Occupational Health Review (ISSN 0951 4600); Nov 1998:25-7; Jan 1999:15-18; March 1999:21-4; May 1999:30-2; July 1999:32-4.

18 Legge TM. Industrial Anthrax, Milroy Lectures 1904. Lancet 1905;1(1 April):843.

19 Legge TM. Industrial Anthrax, Milroy Lectures 1904. Lancet 1905;1(18 March):692

20 Legge TM. Industrial maladies. Oxford Medical 1934:39

21 Stockman S. Departmental Committee on Anthrax (Home Office) Appointed to inquire as to precautions for preventing the danger of infection from the manipulation of wool, goat hair, and camel hair. Vol 3, p276. Evidence and appendices CD 9172 (1918).

22 Kidderminster Times. 14 March 1903. Microfilm. Local Studies Collection, Kidderminster Library.

23 Legge TM. Industrial Anthrax, Milroy Lectures 1904. Lancet 1905;1(25 March):695.

24 Yorkshire Observer. Cited by Kidderminster Shuttle 21 March 1903 Microfilm. Local Studies Collection, Kidderminster Library. 
25 Kidderminster Shuttle. 14 March 1903. Microfilm. Local Studies Collection, Kidderminster Library.

26 Medical Officer of Health. Annual Report 1903. Local Studies Collection, Kidderminster Library.

27 Anon. Anthrax in Worcestershire. Birmingham Post 10 April 1903.

28 Anon. Worcestershire farmers and anthrax. Kidderminster Times 18 April 1903.

29 Legge TM. Industrial Anthrax, Milroy Lectures 1904. Lancet 1905;1(25 March):764-76.

30 Carter T. Anthrax: a global problem with and Italian cure. Conference on the history of occupational and environmental prevention, Rome, Italy, October
1998. International Congress series 1189. Amsterdam: Elsevier Science, 1998:247-51, (ISBN 044450255 6).

31 Chief Inspector of Factories. Annual Report 1906. London: HMSO).

32 Departmental Committee on Anthrax, appointed to inquire as to precautions for preventing the danger from infection from the manipulation of wool, goat hair, and camel hair. Vol 1 Disinfection CD 9057, Vol 2 Report CD9171, Vol 3 Evidence and Appendices CD9172. London: HMSO, 1918.

33 Medical Officer of Health. Annual Report 1903. Local Studies Collection, Kidderminster Library.

34 Medical Officer of Health. Monthly Report 9 February 1903. Local Studies Collection, Kidderminster Library.

\section{Clinical Evidence - Call for contributors}

Clinical Evidence is a regularly updated evidence based journal available worldwide both as a paper version and on the internet. Clinical Evidence needs to recruit a number of new contributors. Contributors are health care professionals or epidemiologists with experience in evidence based medicine and the ability to write in a concise and structured way.

\section{Currently, we are interested in finding contributors with an interest in} the following clinical areas:

Altitude sickness; Autism; Basal cell carcinoma; Breast feeding; Carbon monoxide poisoning; Cervical cancer; Cystic fibrosis; Ectopic pregnancy; Grief/bereavement; Halitosis; Hodgkins disease; Infectious mononucleosis (glandular fever); Kidney stones; Malignant melanoma (metastatic); Mesothelioma; Myeloma; Ovarian cyst; Pancreatitis (acute); Pancreatitis (chronic); Polymyalgia rheumatica; Post-partum haemorrhage; Pulmonary embolism; Recurrent miscarriage; Repetitive strain injury; Scoliosis; Seasonal affective disorder; Squint; Systemic lupus erythematosus; Testicular cancer; Varicocele; Viral meningitis; Vitiligo However, we are always looking for others, so do not let this list discourage you.

\section{Being a contributor involves:}

- Appraising the results of literature searches (performed by our Information Specialists) to identify high quality evidence for inclusion in the journal.

- Writing to a highly structured template (about 2000-3000 words), using evidence from selected studies, within 6-8 weeks of receiving the literature search results.

- Working with Clinical Evidence Editors to ensure that the text meets rigorous epidemiological and style standards.

- Updating the text every eight months to incorporate new evidence.

- Expanding the topic to include new questions once every 12-18 months.

If you would like to become a contributor for Clinical Evidence or require more information about what this involves please send your contact details and a copy of your CV, clearly stating the clinical area you are interested in, to Claire Folkes (cfolkes@bmigroup.com).

\section{Call for peer reviewers}

Clinical Evidence also needs to recruit a number of new peer reviewers specifically with an interest in the clinical areas stated above, and also others related to general practice. Peer reviewers are health care professionals or epidemiologists with experience in evidence based medicine. As a peer reviewer you would be asked for your views on the clinical relevance, validity, and accessibility of specific topics within the journal, and their usefulness to the intended audience (international generalists and health care professionals, possibly with limited statistical knowledge). Topics are usually 2000-3000 words in length and we would ask you to review between $2-5$ topics per year. The peer review process takes place throughout the year, and our turnaround time for each review is ideally 10-14 days.

If you are interested in becoming a peer reviewer for Clinical Evidence, please complete the peer review questionnaire at www.clinicalevidence.com or contact Claire Folkes(cfolkes@bmigroup.com). 